\title{
Reviews on the Application of Effectivités in 2012 Nicaragua and Colombia Case
}

\author{
Tingkai Jia ${ }^{1}$ \\ ${ }^{1}$ China Institute of Boundary and Ocean Studies, Wuhan University, Wuhan, China \\ Correspondence: Tingkai Jia, China Institute of Boundary and Ocean Studies, Wuhan University, Wuhan, Hubei, \\ China. E-mail: jiatingkai2019@163.com
}

Received: January 6, 2022

Accepted: January 24, 2022

Online Published: January 27, 2022

doi:10.20849/ajsss.v7i1.993

URL: https://doi.org/10.20849/ajsss.v7i1.993

\begin{abstract}
Effectivités is a unique principle developed in the process of settling territorial disputes by the International Court of Justice. It is gradually developed in judicial practice and plays a very important role in settling territorial disputes. From the perspective of the case of territorial and maritime dispute between Nicaragua and Colombia, which was tried by the International Court of Justice in 2012, and combined with other cases that applied Effectivités, this paper analyzes and discusses the basic theoretical basis and considerations of the application of this principle by the International Court of Justice, and the relationship between this principle and other applicable sources or rules of international law.
\end{abstract}

Keywords: effectivités, 2012 Nicaragua and Colombia Case, à titre de souverain

\section{Introduction}

The Republic of Nicaragua (hereinafter "Nicaragua") is located in the southwestern Caribbean Sea, bordered by Honduras to the north, Costa Rica and Panama to the south, and across the sea from the Colombian land to the east. The Republic of Colombia (hereinafter "Colombia") is located in the southern Caribbean Sea, bordered by Panama to the west and Venezuela to the east. The two countries were originally Spanish colonies and achieved independence in the early 17th century. After independence, the two States had a sovereignty dispute over the Mosquito Coast in the western Caribbean Sea and the San Andres Islands. The disputed maritime features of the two Parties include the three main islands of the San Andres Islands, namely San Andres, Providencia, and Santa Catalina. (Note 1) In addition, there are disputes over whether some of the islands around these three islands constitute part of the San Andres Islands and their sovereignty, including islands on the Albuquerque, East-Southeast Cays, Roncador, Serrana, Kita Suenio, Serrana and Serranilla and Bajo Nuevo. (Note 2) In order to determine the ownership of sovereignty, the two countries signed the "Colombia and Nicaragua Treaty on Disputed Territories" (hereinafter "1928 Treaty") on March 24, 1928, in which Nicaragua recognized Colombia's sovereignty over the San André Islands and agreed on Lonca Many, Kitasueño and Serrana are disputes between the United States and Colombia. On May 5, 1930, the two States signed the "Protocol of Ratification of the Exchange of Letters" and ratified the "1928 Treaty", stipulating that the San Andres Islands shall not exceed the west longitude 82 longitude to the west. In 1969, Nicaragua issued a permit for oil development and exploration in the disputed sea area, which caused protests in Colombia. In 1972, Colombia and the United States signed the Treaty of Kitasueño, Roncado and Serrana (, and Nicaragua protested. In July 1979, Nicaragua claimed that the 1928 Treaty was invalid, and Colombia protested this. On December 6, 2001, Nicaragua brought the territorial and maritime dispute between the two countries to the International Court of Justice. The court made a judgment on the substantive issues of the case on November 19, 2012.

The court first considered the 1928 Treaty and Uti possidetis juris, and believed that the dispute between the two parties could not be resolved under these two rules, and finally made a judgment mainly based on effectivités. In this case, Colombia submitted a large amount of evidence of effective governance to the International Court of Justice, proving that Colombia has exercised open, peaceful and sustained sovereignty over these islands over the past 180 years. For example, for the San Andres Islands, Colombia has formulated laws and regulations involving fishing, economic activities, immigration, search and rescue operations, public works, and environmental issues; implemented criminal legislation, supervision, control activities, and protection and rational use of natural resources And other scientific research; authorized a third party to conduct oil and gas 
exploration in the waters surrounding the archipelago, etc. These activities are also fully consistent with the 1928 Treaty and the 1930 Protocol. In contrast, Nicaragua did not provide any evidence of such sovereignty activities, and has not raised any protests in the past 150 years, so the court finally decided that the sovereignty of the disputed marine features belonged to Colombia. (Note 3)

\section{Considerations for Effectivités}

\subsection{Elements of Effectivités}

In contemporary international law theories, it is generally believed that effective control must be a conscious act of sovereignty, that is, effective control must have two basic elements: First, subjectively, effective control requires a country to have the subjective intention of a sovereign to manage the relevant territory. In the event of a territorial dispute, the state must effectively protest the relevant actions in the name of the sovereign, and certain measures must be taken when necessary, otherwise it may be regarded as acquiescence. Secondly, objectively, a country must have a sovereign behavior that shows its actual control. And the act of demonstrating the purpose of sovereign must meet four conditions, namely peaceful, actual, sufficient and continuous. However, how to constitute effectiveness is relative and depends on the geographic nature of the region, the intensity of controversial claims, and other factors such as international reactions. The so-called "peaceful" control means that from the very beginning, no other country has made a claim for sovereignty. The protest behavior of other Parties alone is not enough to constitute a threat to peaceful control. However, if one of the Party consistently protest and refute the protest for a long period of time, it may not constitute peaceful control. In addition, "actual" control refers to the existence of control activities, not just the control claimed on paper or nominal control. Of course, there is no need to control every point on the land. The specific situation needs to be based on the characteristics of the land, the number of residents and other factors. "Sufficient" control means that the behavior of the state must provide the minimum protection for residents in accordance with international law, and the degree of sufficient needs to be considered based on specific circumstances. The "continuous" control refers to uninterrupted control. It also needs to be considered based on specific cases. However, continuous control is regarded as the most important condition in the activities of demonstrating the purpose of governance.

The judgment of this case further clarified the elements and considerations of effective governance. In its judgment, the court held that Colombia has managed the disputed islands continuously "à titre de souverain" for decades, and these management activities did not show that it was protested by Nicaragua before the critical date. The opposition therefore constitutes Colombia's effectivités of these disputed islands. (Note 4) This was actually a general theory and practice that recognizes and continues to use the subjective and objective elements of effectivités. In this case, the court reviewed various activities taken by Colombia against the disputed islands prior to 1969, including public administration and legislation, control of economic activities, establishment of public facilities, enforcement measures, military patrols, searches and rescue operations, recognition of Germany's consular representation, etc., that these activities are all acted à titre de souverain. Moreover, after the critical date in 1969, Colombia continued to take sovereignty actions against the disputed islands, especially the legislation related to land management, the management of fishery activities and related law enforcement measures, the maintenance of lighthouses and buoys, and naval inspections. The court held that these activities were a normal continuation of à titre de souverain activities before the critical date. (Note 5) Therefore, the court held that these activities evidences can be considered as factors in the trial of this case. In addition, the court also examined other related acts and factors, including the default behavior of Nicaragua, the position of a third country, and the value of the relevant maps. Although these related actions and factors cannot be used as evidence of sovereignty, they also support Colombia's claim to a certain extent.

\subsection{Recognition Standards of Effectivités Are Relative}

When applying effective control rules, the key issue is to determine what types of behaviors in practice and to what extent these activities can constitute effective control. Effective control is a relative concept. Observing the relevant cases of the International Court of Justice and other international judicial institutions applying effectivités, many successful States do not have absolute rights, but are relatively superior to competing countries. In other words, the important factor that should be considered is the degree of sovereignty activities carried out by States that have oppositional claims to the disputed islands. As the Permanent Court of International Justice stated in the Case concerning Legal status of Eastern Greenland: "It is impossible to read the records of the decisions in cases as to territorial sovereignty without observing that in many cases the tribunal has been satisfied with very little in the way of the actual exercise of sovereign rights, provided that the other State could not make out a superior claim. This is particularly true in the case of claims to sovereignty over areas in thinly populated or unsettled countries." (Note 6) 
By analyzing the cases of the International Court of Justice, when judging which party can make a more advantageous claim, the International Court of Justice mainly weighs and compares from two aspects: first, whether it actively implements sovereign activities with the intention of possessing the disputed territory; second, whether it is effective to protest against the sovereignty activities of other parties with intent to possess. In this case, with regard to Colombia's submission of a large amount of evidence to prove that it exercised activities that reflect national sovereignty, Nicaragua proposed that Colombia's legislative and administrative measures did not explicitly mention the 7 disputed islands in this case, but only have general characteristics, and some of these actions are after the critical date. (Note 7) The International Court of Justice pointed out that, as stated in the Eastern Greenland case in 1933, a country's sovereignty over smaller marine structures only needs to be based on a relatively modest demonstration of national power in terms of quality and quantity. If another country cannot make a more advantageous claim, the aforementioned country will obtain territorial sovereignty even if it rarely actually exercises sovereignty over the disputed area. (Note 8) In this case, Colombia has continuously and consistently implemented sovereignty over the disputed maritime features for decades. This exercise of sovereignty is public and has not encountered any protests from Nicaragua before the critical date; after the critical date, it has taken such actions as the legislation on local institutions, the regulation and implementation of fishery activities, the maintenance of lighthouses and buoys, and naval visits are the continuation of their previous actions and are therefore recognized. In contrast, Nicaragua did not provide any evidence that it had previously performed similar actions. (Note 9) Therefore, it can be clearly concluded that Colombia's proposition is more advantageous.

In addition to the relativity of the validity of the evidence in a specific case by the parties, in different territorial dispute cases, the court need to consider the specific conditions of different disputed territories. For some remote, uninhabited or seldom-inhabited islands similar to the islands in dispute in this case, considering their economic significance, the actions taken against these islands may be very limited. The International Court of Justice believes that "sovereignty over smaller maritime features... can be established on the basis of a relatively small amount or quality of national power." (Note 10) For example, in the 2002 Case Concerning Sovereignty over Pulau Ligitan and Pulau Sipadan, Malaysia's activities only included legislation on the collection of sea turtle eggs, issuing permits and establishing bird sanctuaries. However, the International Court of Justice believes that although these activities are limited in number, they include legislative, administrative and quasi-judicial acts, and they have lasted for a long time. On the one hand, Indonesia has not made any sovereignty enforcement actions recognized by the International Court of Justice, and on the other hand, it has not protested against Malaysia's actions, so Malaysia's proposition has more advantages. (Note 11)

\subsection{Specificity Requirements of Evidence}

Regarding Colombia's sovereignty actions on the maritime features of the dispute, Nicaragua argued that only when legislative and administrative actions are "unquestionably specifically related to the disputed territories" can they be considered to constitute a relevant display of power. However, Colombia's legal provisions and administrative actions on the San André Islands are of general nature, not specific to the islands. In response to this challenge, the court pointed out that although most of Colombia's sovereignty acts are implemented in the seas that include all the features of the dispute, it has implemented sovereign acts not only on the seas surrounding the disputed maritime features, but also on the maritime features themselves. (Note 12) For example, in April 1871, the Colombian Congress issued a law allowing administrative agencies to rent out the right to collect bird droppings and coconuts, specifically mentioning the Albuquerque Atoll, Roncado and Kitasueño. It can be seen from this that, regardless of the legislative, judicial, or administrative nature of the recognizable sovereign implementation, it must specifically refer to the disputed territory and have a direct connection with the disputed territory, and cannot only involve the disputed territory in a general scope. Similarly, in the 2008 Singapore and Malaysia Pedra Branca, Middle Reef, and South Reef Island Sovereignty Case, Malaysia passed legislation in 1969 to expand its territorial waters from 3 nautical miles to 12 nautical miles, thus claiming that the legislation "expanded Malaysia's territorial waters" Pedra Branca is within the scope of water," and the court held that the legislation did not specify the applicable area, but was only applicable in a general sense. Therefore, it could not prove that the act of sovereignty enforcement was carried out on Pedra Branca. (Note 13) In fact, in territorial disputes, all evidence requires specificity and clarity, and is directly related to the disputed territory, including when it is judged based on treaties and uti possidetis juris. In this case, the International Court of Justice held that Article 1 of the Treaty of 1928 clearly mentioned that San André Island, Providencia Island and Santa Catalina Island belong to Colombia, so the ownership of these three islands can be determined according to the treaty. In contrast, the 1928 Treaty and the Spanish administrative decree submitted by the parties did not specifically mention the names of other disputed maritime features, so their ownership cannot be determined 
solely by the treaty and uti possidetis juris.

\section{The Status and Rank of Effectivités}

In hearing the issue of the sovereignty of the disputed islands, the court separately considered the 1928 treaty proposed by the parties and uti possidetis juris, but finally applied effectivités cited by Colombia. The court's reasoning was: The 1928 treaty and the Spanish administrative decree submitted by the parties did not specifically mention the names of other disputed maritime features. Therefore, the sovereignty dispute over the disputed islands could not be resolved only by the treaty and uti possidetis juris, so the court began to try to determine the sovereignty of the disputed island on the basis of effectivités to resolve the territorial dispute. It can be seen that effective control rules are not absolute and priority rules that resolve the ownership of territorial sovereignty. There are prerequisites for application.

In the 1986 Case Concerning the Frontier Dispute between Burkina Faso and Mali, the International Court of Justice explained the legal effect of effective control in four cases: " Where the act corresponds exactly to law, where effective administration is additional to the uti possidetis juris, the only role of effectivite is to confirm the exercise of the right derived from a legal title. Where the act does not correspond to the law, where the territory which is the subject of the dispute is effectively administered by a State other than the one possessing the legal title, preference should be given to the holder of the title. In the event that the effectivite does not co-exist with any legal title, it must invariably be taken into consideration. Finally, there are cases where the legal title is not capable of showing exactly the territorial expanse to which it relates. The effectivite can then play an essential role in showing how the title is interpreted in practice." (Note 14) This paragraph illustrated the limited effect of effectivités: it can only serve as a confirmation and supplement.

Of the 14 territorial disputes heard by the International Court of Justice, nine of them gave priority to the applicability of the treaty. In such cases, as long as a country concerned proposes a border treaties that can resolve territorial sovereignty disputes, the International Court of Justice will give priority to the validity and applicability of the treaties, and secondly consider other claims of the Parties concerned. If the treaties can resolve territorial sovereignty disputes, the judgment is generally based on them, and effectivités that contradict the provisions of the treaty are considered illegal. Only when the treaties cannot determine the ownership of territorial sovereignty can it be possible to consider the application of effectivités.

In addition, there are 6 cases that considered uti possidetis juris. In such cases, the logic of the International Court of Justice is: First, if it is a territorial sovereignty dispute between newly independent States that originally belonged to the same colonial State, it is bound to give priority to uti possidetis juris; secondly, if there is a demonstrable boundary, even if one Party claims effective control, it will be considered illegal; finally, effectivités will be considered only when the boundary cannot be proven and uti possidetis juris cannot be applied. It can be seen that treaties and uti possidetis juris have priority in the settlement of territorial disputes, and they constitute the preconditions for the application of effectivités. In this case, both Parties claimed uti possidetis juris and presented a series of relevant laws or statutory evidence. According to previous case law, the court held that if uti possidetis juris was applied in this case, the laws of the Spanish colonial period should be applied, but neither Party listed any such laws or decrees. Moreover, the court further held that even if there was such a law, it is entirely possible that it had not made any clear and definite provisions on the attribution of these marginal, almost uninhabited, and economically insignificant areas. The court therefore held that neither Party could establish their rights to the disputed islands in accordance with uti possidetis juris, and decided to apply the principle of effectivités.

In some other territorial dispute cases, the Parties involved have also submitted evidence related to history to the International Court of Justice to prove that they have inchoate title, or to support the claim to uti possidetis juris. For example, in the 1953 The Minquiers and Ecrelzos case, both the United Kingdom and France presented a large amount of evidence involving ancient rights. The International Court of Justice considered that, because the validity of ancient rights evidence is complicated, the decisive evidence in this case was not a presumption of what happened in ancient times, but the evidence directly related to effectivités of the two islands, so the court subsequently focused the case on the actual exercise of the sovereignty of both parties in modern times. (Note 15) To prove the original acquisition and legal rights of the territory, there are various problems and great difficulty in proof. Some historical evidence often needs to go back hundreds or even centuries ago. This presents many difficulties for the Parties to the proceedings and the International Court of Justice. First, this requires the country concerned to collect sufficient and sufficient historical evidence, and to prove the authenticity of the historical evidence again. Secondly, this requires the ICJ not only to be familiar with the complex current dispute environment, but also to be familiar with complex local historical data, and to make value judgments on outdated, 
abandoned, and incomplete historical archive materials to determine whether they are probative. This is undoubtedly a huge challenge. Therefore, some evidences concerning the original acquisition of sovereignty or related rights may be vague due to historical reasons and often fail to receive support in the proceedings of the International Court of Justice.

In summary, in the long-term judicial practice, the International Court of Justice has formed a trend of applying the principle of effective control to resolve territorial disputes. According to the general logic of application of law, effectivités, as a special customary international law principle for resolving territorial or maritime disputes, should belong to a "residual rule". It can only have room for application or play a complementary role when there is no or lack of other superior sources of general international law or legal rights. However, due to considerations of various practical factors, the International Court of Justice tends to prefer effectivités with a certain strength orientation in its judicial practice, while the uti possidetis juris based on certain titles sometimes does not applicable. Compared with the activities à titre de souverain, the proof value of historical evidence of original sovereignty or other legal rights is relatively small.

\section{Conclusion}

This case is the 14th case involving territorial and border disputes in which the International Court of Justice made a judgment on substantive issues, and it is also the sixth case to which effectivités are finally applied. It can be seen from this ratio that effectivités plays an important role in territorial dispute settlement. On the one hand, effectivités emphasizes the peaceful and continuous implementation of sovereignty over disputed territories, which can objectively and reasonably reflect the state's attitude towards territorial ownership; on the other hand, the proof standard for effectivités is relative. Through comparison, it is bound to be able to determine the party making a more superior proposition, so that the gaps in other sources can be effectively filled. In an anarchic international society, this has important practical significance for the stability and peace of the international order.

In addition, the ICJ seems to have confirmed the level of international legal sources that should be applied in the trial of the sovereignty of the disputed islands. In this case, the performance is: give priority to the validity of the treaty, then consider the "maintaining principle", then effectivités, and finally other evidence. This rule of judgment makes judicial activities more certain and predictable, improves the judicial authority and credibility of the International Court of Justice, strengthens the confidence of relevant countries to resolve island disputes through international legal channels, and is conducive to the formation of international customary law.

It is particularly noteworthy that these six cases are all related to island sovereignty. This is mainly determined by the characteristics of the current territorial sovereignty disputes: with human understanding and development of the earth and the development of the international community, most land has been able to determine the ownership of sovereignty, and territorial sovereignty disputes are mainly concentrated in marginal areas, especially far away from land and uninhabited island. Due to the limited economic value and military significance of these islands in history, human activities are generally small, and the possibility of a treaty that accurately mentions these territories is relatively small, and there is a lack of definite and absolute evidence to prove the original titles. (Note 16) In this context, effectivités will play a more important role in handling disputes over these features.

However, as mentioned above, in the absence of an applicable treaty, due to the long and complicated historical evidence, the parties concerned and international judicial institutions such as the International Court of Justice have to collect, analyze, and judge its authenticity and validity. Objectively there is considerable difficulties. Therefore, international judicial institutions may subjectively tend to apply effectivités and there is a possibility that the principle of effective control may be abused. According to the judgment logic of the International Court of Justice, effectivités itself has certain strength-oriented factors. In other words, whoever has the strength to conduct more effective supervision of the disputed islands and has more evidence is likely to obtain the disputed territory. Therefore, in order to ensure that the parties concerned have more effective control over the disputed territories or take the initiative in negotiations, they are very likely to adopt more powerful and effective governance measures, thereby exacerbating the current heat of territorial disputes such as island sovereignty disputes in the relevant trend. Undoubtedly, this is not conducive to the peaceful settlement of the territorial disputes of the countries involved, and it may also shake the international political order.

Considering this case and the related territorial sovereignty dispute cases, there is also something worthy of consideration and vigilance for my country, which may become a party to a territorial dispute. First of all, the thinking of the International Court of Justice in this case is still to examine the applicability of the relevant treaties and the relevant evidence to uti possidetis juris. This shows that compared with treaties and established 
international customary law, effectivités is still in a subordinate and complementary position. Therefore, when there are no applicable treaties, the proving effect of other original title and the evidence of uti possidetis juris and other international customary law rules still has a relatively advantageous proving force. Therefore, we should still pay attention to the collection and research of such evidence. Secondly, due to the difficulty of collecting, collating and proving complex historical evidence, as well as the judgment of international judicial institutions on these evidences, and observing the judicial practice of territorial disputes, the possibility of applying the principle of effective control to judge territorial disputes is increasing day by day. Therefore, we should have enough understanding of the role of effective control.

Considering the constituent elements of effectivités, we should pay attention to effective management over the features we claim, and we should try our best to reflect sovereignty in management activities, such as formulating relevant domestic laws and regulations to govern and deploy military troops and so on. Secondly, considering the relative nature of the determination standards, we also need to be alert to the actions and claims of countries that oppose us. In particular, public officials of the State should be alert to statements involving disputed territories on all occasions. In addition, considering that evidence is required to be specific in territorial sovereignty disputes, when conducting management activities, we should pay attention to clearly showing the names and locations of relevant disputed features, so as to further strengthen the effectiveness of our evidence.

\section{References}

Case Concerning Sovereignty over Pedra Branca/ Pulau Batu Puten, Middle Rocks and South Ledge (Malaysia/ Singapore). Judgment of 23 May 2008.

Case Concerning Sovereignty over Pulau Ligitan and Pulau Sipadan (Indonesia/Malaysia). I. C. J. Reports 2002.

Case Concerning the Frontier Dispute (Burkina Faso/Republic of Mali). I. C.J. Reports 1986.

Land, Island and Maritime Frontier Dispute (EI Salvador/Honduras: Nicaragua intervening), Judgment. I.C.J. Reports 1992.

Legal status of Eastern Greenland, Judgment. (1933). P.C.I.J. Series A/B, No. 53.

Schwarzenegger, G. (1957). Title to Territory: Response to a Challenge. American Journal of International Law, 51(2), 309.

Territorial and Maritime Dispute (Nicaragua v. Colombia). Judgment of 11 November 2012.

Territorial and Maritime Dispute between Nicaragua and Honduras in the Caribbean Sea (Nicaragua v. Honduras). Judgment, I.C.J. Reports 2007(11).

The Minquiers and Ecrelzos case, Judgment. ICJ Reports 1953.

\section{Notes}

Note 1. Territorial and Maritime Dispute (Nicaragua v. Colombia), Judgment of 11 November 2012, para. 22.

Note 2. Territorial and Maritime Dispute (Nicaragua v. Colombia), Judgment of 11 November 2012, para. 24.

Note 3. Territorial and Maritime Dispute (Nicaragua v. Colombia), Judgment of 11 November 2012, para.103.

Note 4. Territorial and Maritime Dispute (Nicaragua v. Colombia), Judgment of 11 November 2012, para.83.

Note 5. Territorial and Maritime Dispute (Nicaragua v. Colombia), Judgment of 11 November 2012, para.83.

Note 6. Legal status of Eastern Greenland, Judgment, 1933, P.C.I.J. Series A/B, No. 53, p.46.

Note 7. Territorial and Maritime Dispute (Nicaragua v. Colombia), Judgment of 11 November 2012, paras.67.

Note 8. Legal status of Eastern Greenland, Judgment, P.C.1.J. Series A/B, No. 53, 1933, p.46.

Note 9. Territorial and Maritime Dispute (Nicaragua v. Colombia), Judgment of 11 November 2012, paras.80-84.

Note 10. Territorial and Maritime Dispute between Nicaragua and Honduras in the Caribbean Sea (Nicaragua v. Honduras), Judgment, I.C.J. Reports 2007(11), para. 174.

Note 11. Case Concerning Sovereignty over Pulau Ligitan and Pulau Sipadan (Indonesia/Malaysia), I. C. J. Reports 2002, para.685.

Note 12. Territorial and Maritime Dispute (Nicaragua v. Colombia), Judgment of 11 November 2012, para. 81. 
Note 13. Case Concerning Sovereignty over Pedra Brancal Pulau Batu Puten, Middle Rocks and South Ledge ( Malaysia/ Singapore), Judgment of 23 May 2008, p. 70.

Note 14. Case Concerning the Frontier Dispute ( Burkina Faso/Republic of Mali), I. C.J. Reports 1986, p. 587.

Note 15. The Minquiers and Ecrelzos case, Judgment, ICJ Reports 1953, p. 56.

Note 16. Land, Island and Maritime Frontier Dispute (EI Salvador/Honduras: Nicaragua intervening), Judgment. I.C.J. Reports 1992, para. 333.

\section{Copyrights}

Copyright for this article is retained by the author(s), with first publication rights granted to the journal.

This is an open-access article distributed under the terms and conditions of the Creative Commons Attribution license (http://creativecommons.org/licenses/by/4.0/). 